
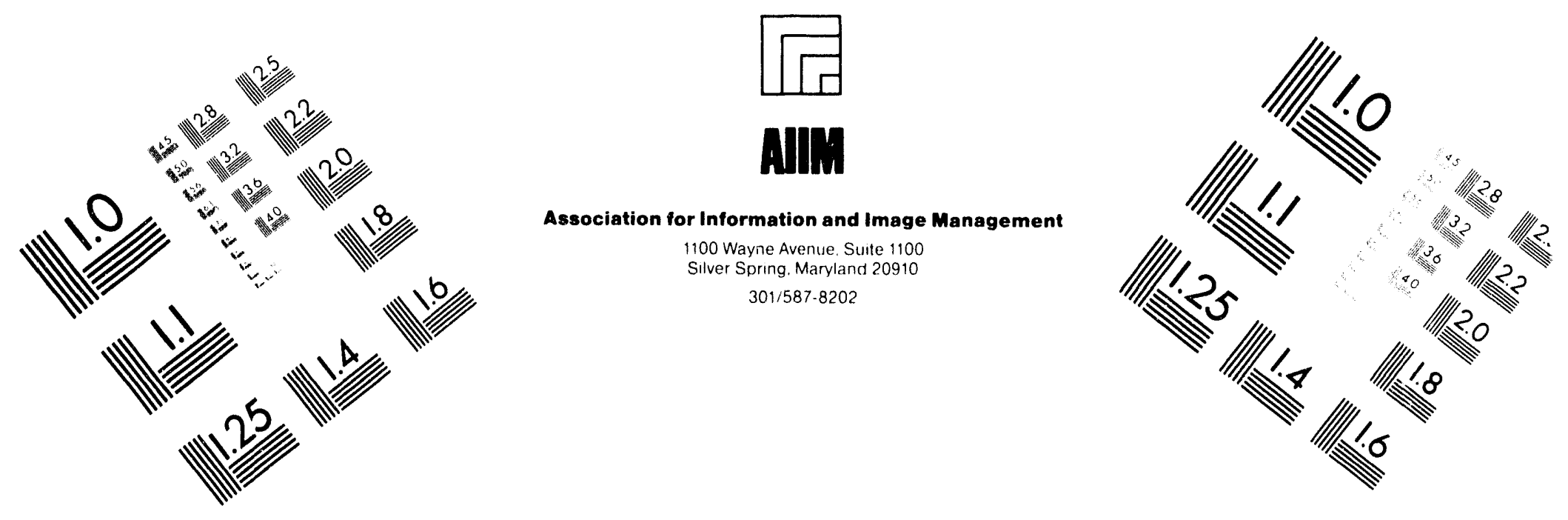

\title{
Centimeter
}

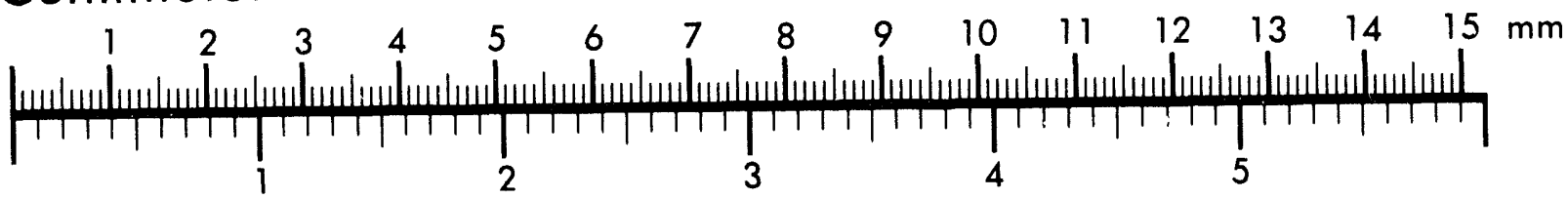
Inches
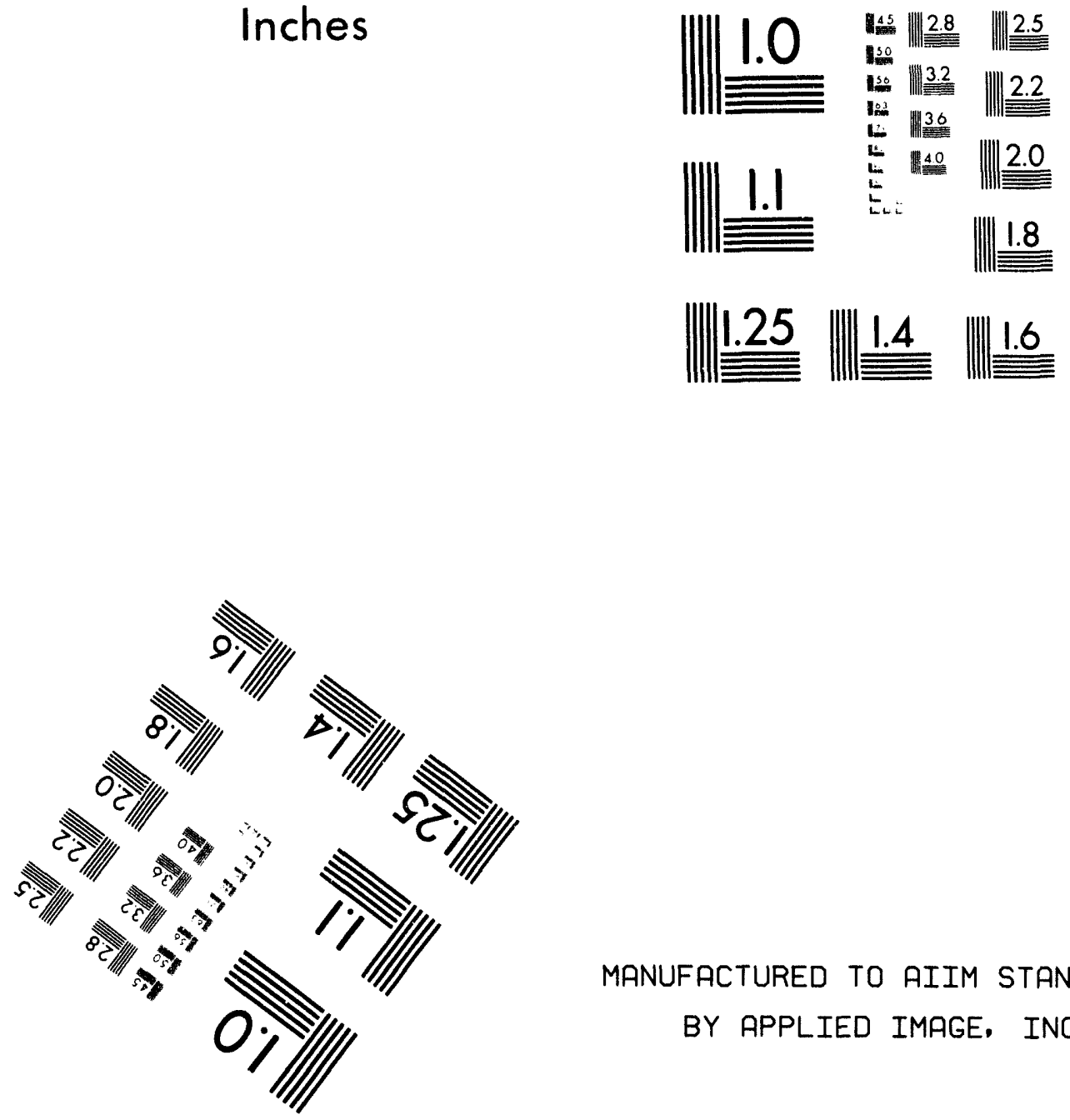

MANUFACTURED TO AIIM STANDARDS

BY APPLIED IMAGE, INC.

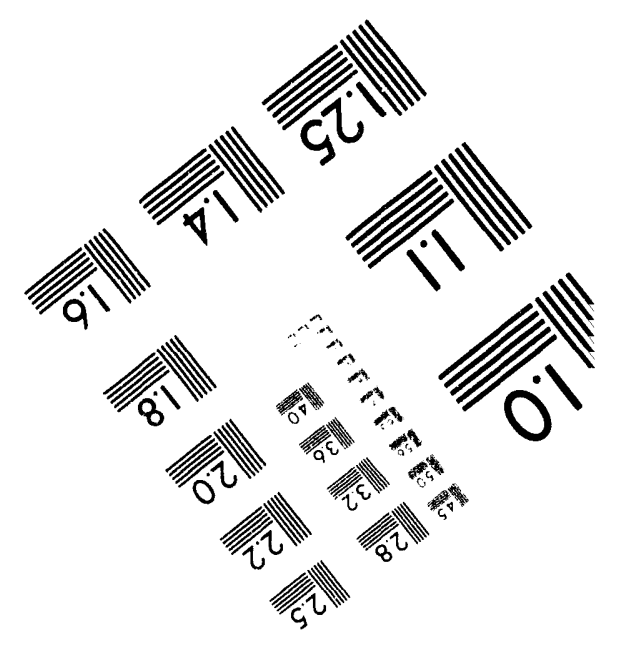



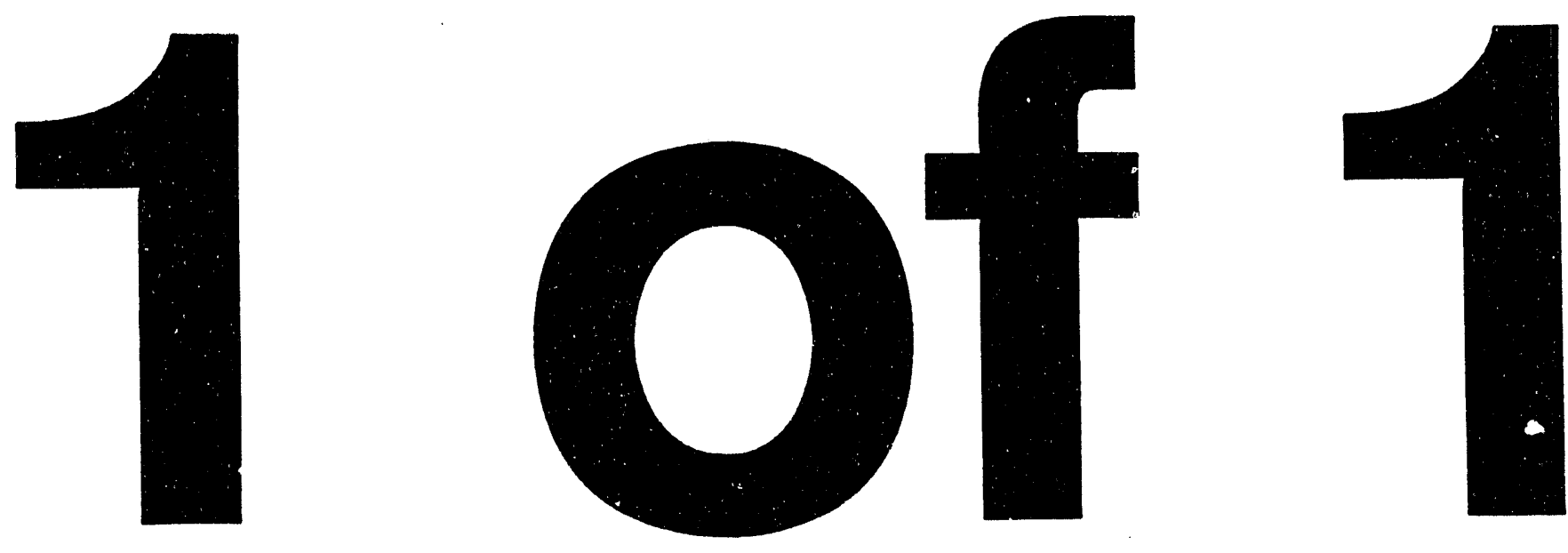
RICHLAND, WASHINGTON

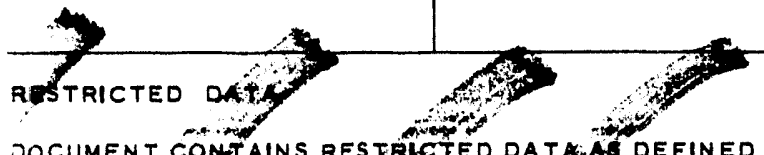
DOCUMENT CONFTAINS RESTRLCEDE DATA DOEFINED IE ATOMEC ENEREY ACA6OY 1954 ITOHPANSMITTAL HE DISELOSÚRE UF ITSCONTENTS MATNY MANNEGTO VAYAIVAIZED PER S PROHI ED The

DTHER OFFICIAL CLASSIFIED INFORMATION

MATERIAL CONTAINS INFORMATION AFFECTING THE ONAL DEFENSE OF THE UNITED STATES WITHIN THE ING OF THE ESPIONAGE LAWS, TITLE 18, U.S.C., SECS IND 794, THE TRANSMISSION OR REVELATION OF H IN ANY MANNER TO AN UNAUTHORIZED PERSON IS IIBITED BY LAW.

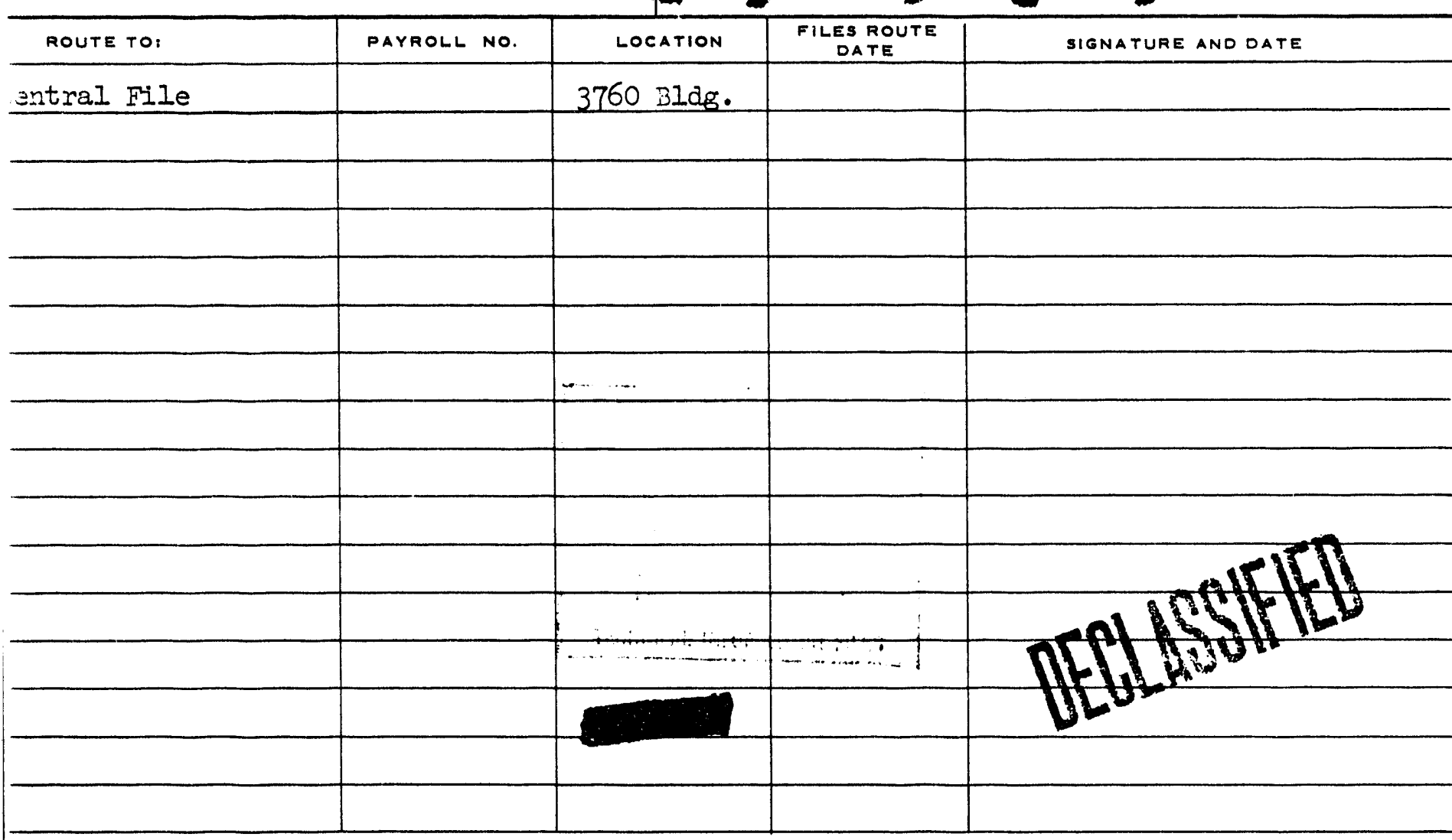
- UNAUTHORIZER PERSON MWY HAVE AGCESS TO IT. WHEN NOT IN.

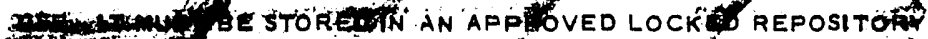

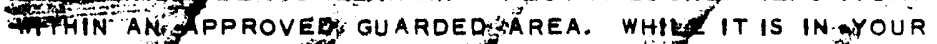

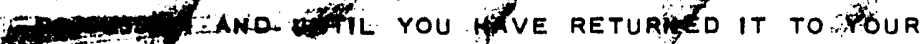
CLASSIFY D DOCUMENT RESPONSIBILITY STATION, IT IS YOYR

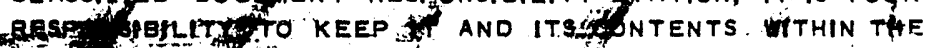

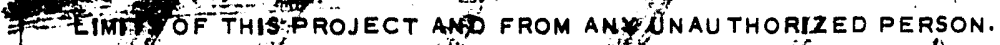

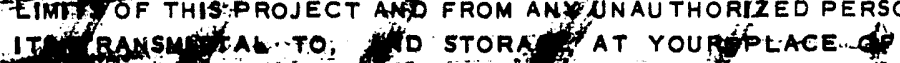

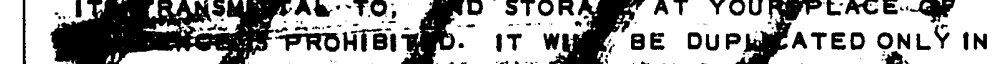

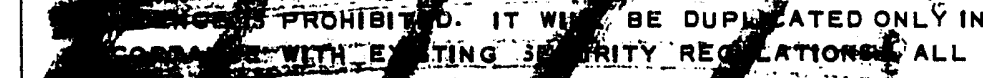

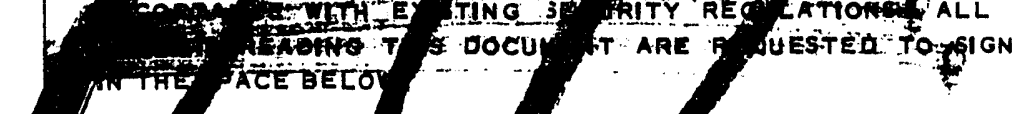
? MICMLAMD WASH , 


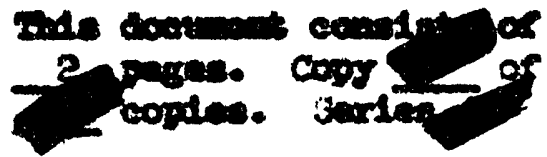

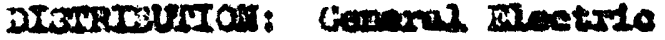
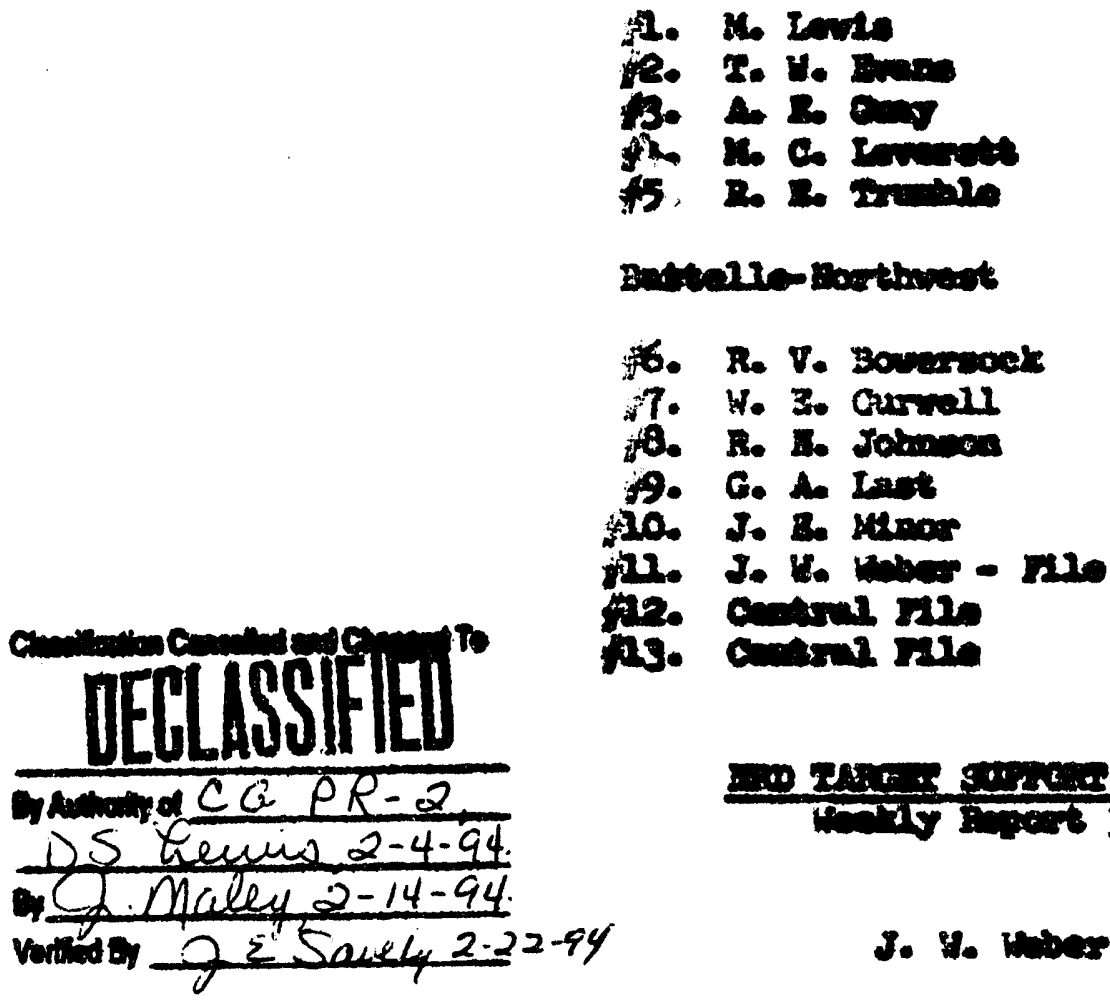

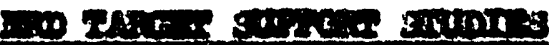

rocty 10003

\section{H. Inower}

Mrex 11, 1965

Exivigran max

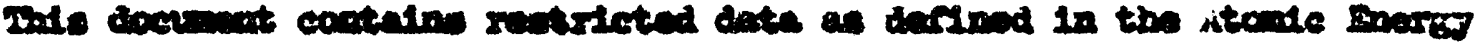

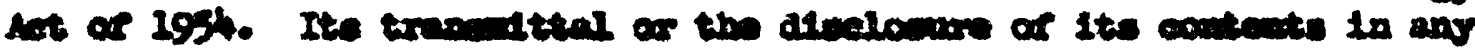

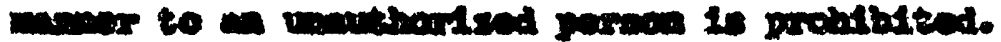

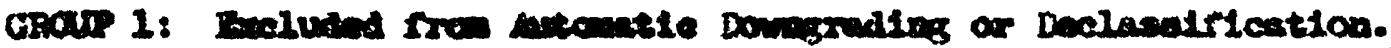

DISTRIBUTION OF THIS DOCUMENT IS UNLIMITED

\section{DISCLAIMER}

This report was prepared as an account of work sponsored by an agency of the United States Government. Neither the United States Government nor any agency thereof, nor any of their employees, makes any warranty, express or implied, or assumes any legal liability or responsibility for the accuracy, completeness, or usefulness of any information, apparatus, product, or process disclosed, or represents that its use would not infringe privately owned rights. Reference herein to any specific commercial product, process, or service by trade name, trademark, manufacturer, or otherwise does not necessarily constitute or imply its endorsement, recommendation, or favoring by the United States Government or any agency thereof. The views and opinions of authors expressed herein do not necessarily state or reflect those of the United States Government or any agency thereof. 
Tos Ho inds, vanges

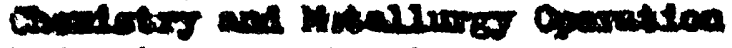

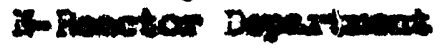

Suct 2. He :umbers

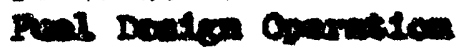

Bestelle-iloxtbunim

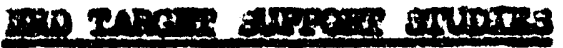
Hong 3

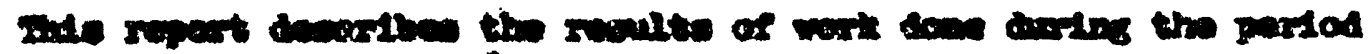

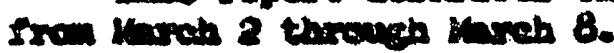

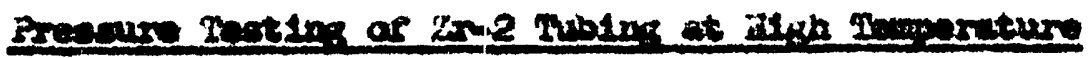

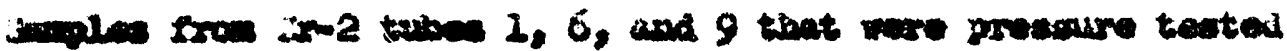

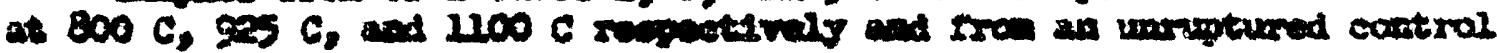

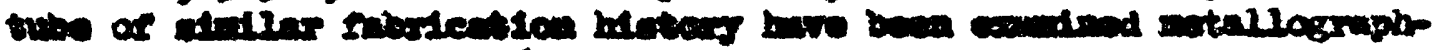

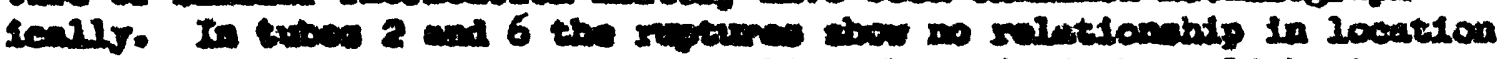

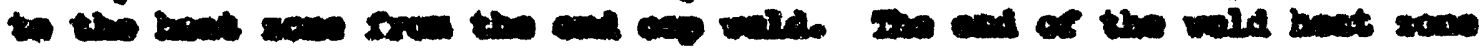

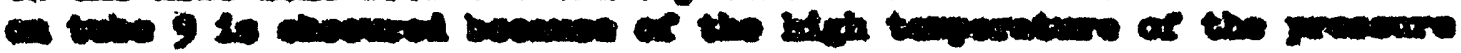

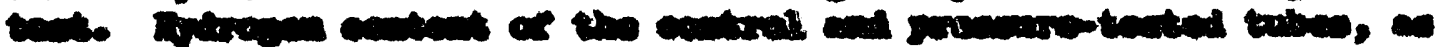

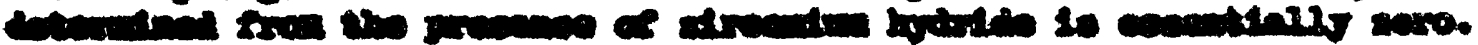

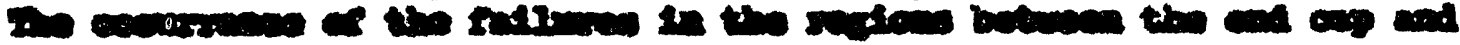

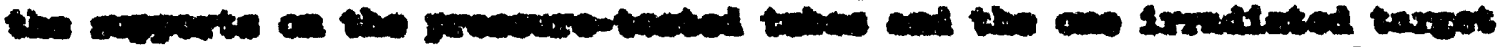

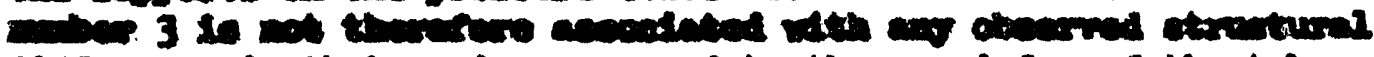

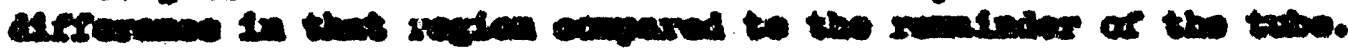

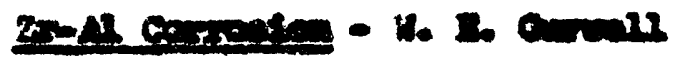

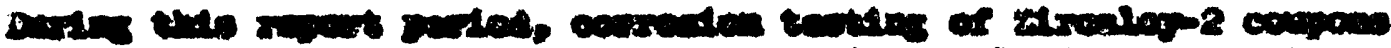

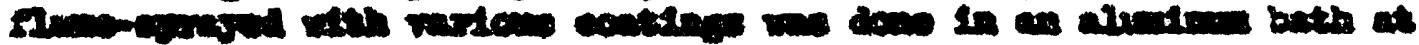

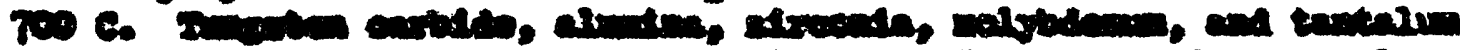

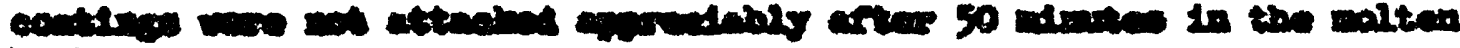
bon.

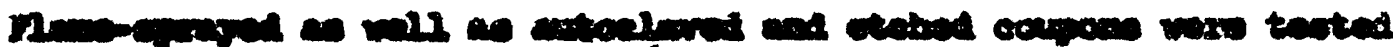

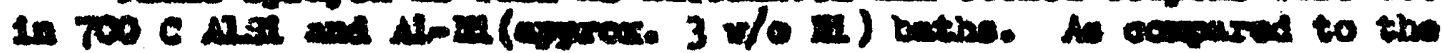

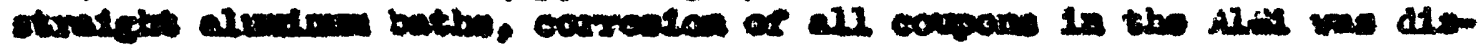

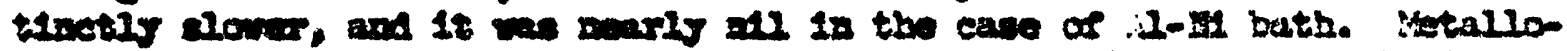

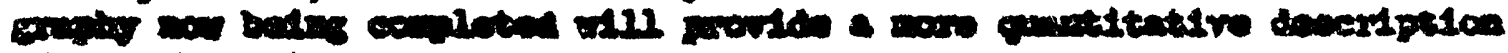
co the swore terese.

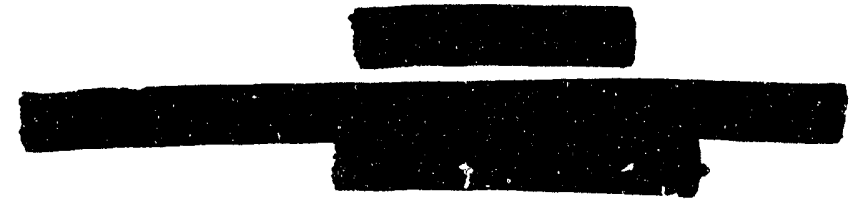




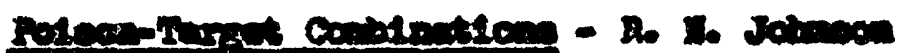

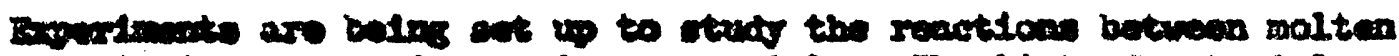

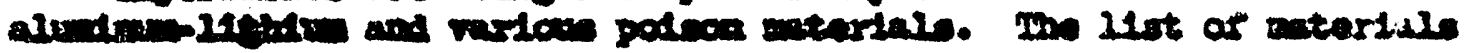
now Inoluine:

$$
\begin{aligned}
& \text { 3. } 40 \text { ad in od } \\
& \text { 2. a } 0 \\
& \text { 3. } 01 \\
& \text { 4. } \cos _{3}
\end{aligned}
$$

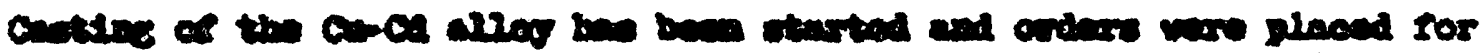

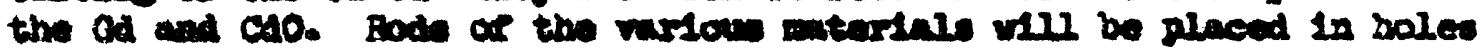

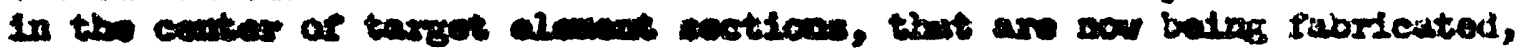
and then bested for variou them at 500 to $700 \mathrm{C}$ to stuty the semetion rutec.

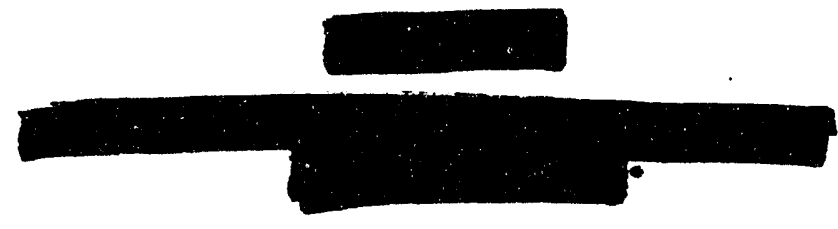



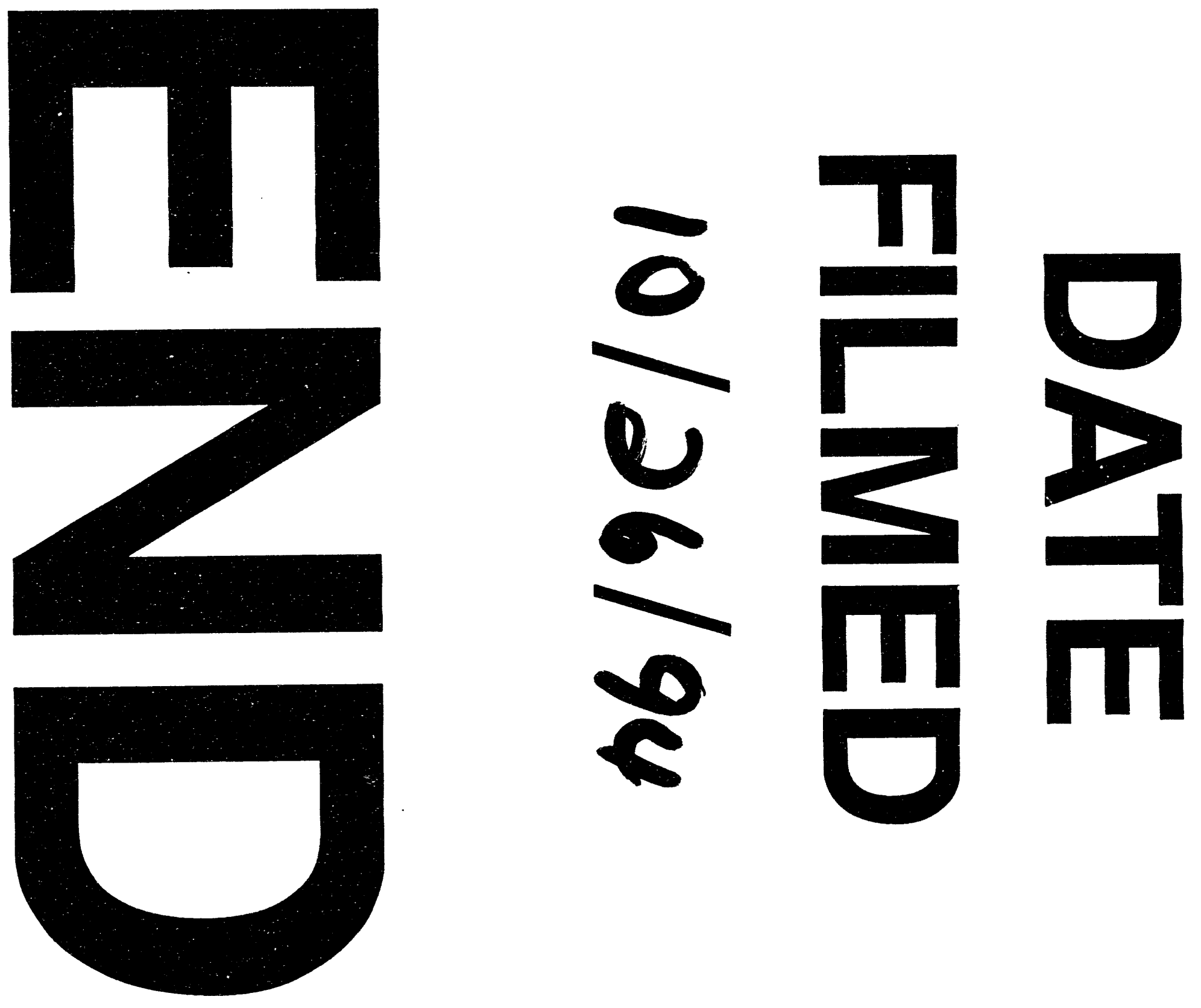
